\title{
FUN VOCABULARY LEARNING IN EFL CLASSROOM THROUGH CHARADES GAME: WHY NOT?
}

\author{
Nur Halimah', Megawati Basri ${ }^{2}$ \\ 1cayu1633@gmail.com \\ ${ }^{2}$ Nininglaturake@gmail.com
}

\begin{abstract}
The purposes of this paper are to portray charades game in learning vocabulary mastery in EFL classroom and tell the readers that this game is effective in every skill. This game has the activities like teamwork, served some topic given by the teacher, then she list the mistakes, then the last is reviewing by the teacher. The game enables the students to acquire new experiences in foreign language then fun and enjoyable environment is able to raise students' motivation in learning. Vocabulary mastery is one of the most effective skills which may improve the students' achievement in learning a language in the classroom. The students who have great quantities of vocabularies will bring them to be a great in mastering four crucial skills in English. They could easily do their task in the process of learning without any panicky or something disturbs their mind about the word. Meanwhile, English as a foreign language in Indonesia is still hard to get to serve for Indonesian students especially. Some of them have not remember well yet single word or vocabulary even though they have learned for almost twelve years if we count from primary school till college.
\end{abstract}

Keywords: vocabulary mastery, charades game.

\section{INTRODUCTION}

Vocabulary is very crucial to support students' ability in English, but nowadays it becomes the problem in learning English, for instance many students cannot express word well because they less vocabulary mastery and difficult to remember the new word. Mostly, they found the difficulties on how to increase their vocabulary skill. In learning process, the students confuse what the teacher said even do not know what the exactly the meaning of it. So, they work hard in remembering and listing every single new word. Furthermore, in their mind they think that English is too hard. This situation is different from the other students who master in vocabulary. They will easy to join the class and fun to do every task given by the teacher. Most of the time, the teacher failed to conduct vocabulary lesson in the classroom. It happens because the teacher often could not create an interesting environment in the classroom during the lesson. The teacher often asks students to memorize a number of word lists every day. Besides that, Wanzek (2003) suggests that the goal in vocabulary lesson is that the learner can understand the meaning of new words. The instructional components of a vocabulary lesson include describing the meaning of words in a sentence or identifying synonyms and antonyms of a given word. For that purpose, teacher's creativity is needed mostly. Whereas, success in learning often depends on the number of senses which are used in the learning process Allen (1983). When students can touch, hear, and see the word that names it, there is a possibility that the word will be remembered by the students. The using of Charade game can be one of the interesting ways in enriching students' vocabulary. The students can expand their vocabulary because the game is interesting and stimulating. Charade is an acting game. There are many kinds of Charades that people played; word, phrase, action, and feeling. This game is due to 
the students act by their body language without speaking and then the other students guess what exactly vocabulary that given by the teacher or their friends.

\section{LITERATURE REVIEW}

2.1 Definition of Vocabulary

Vocabulary is a core component of language proficiency and provides much of the basis for how well learners speak, listen, read and write Richards and Renandya (2004). Therefore, it is as a central of language. In learning English, we learn to practice to speak, listen, write and read. Those processes involve the sentences even word. English is complex because there are many knowledge to guide us to be master in English such as; grammar, vocabulary, pronunciation, translation, spelling and others. That is why the vocabulary mastery is extremely needed to the students. The teacher must serve great environment in learning. Teaching vocabulary is important aspect that teacher should pay attention to. It is because vocabulary may effect to students' ability in acquiring the four skills; speaking, listening, reading and writing. The various approaches in foreign language teaching have led to different values and method in teaching vocabulary. Nunan (2000) states that the focus in the vocabulary class is how to encourage the students to develop strategies to infer the meaning of new words from context occur and teaching them to use arrange of clues both verbal and non-verbal to determine the meaning. Teaching vocabulary deals with knowing the meaning from the word. The teacher should teach the word that related to the students life by using the appropriate strategy, media, and technique and adjust them best on the level of students. According to Cameron (2001) teaching vocabulary focuses on helping students to build up knowledge of words also it will be able to students to use the language efficiently and successfully. It means that teaching vocabulary must be carefully to make students can enjoy the learning and attract with the English subject

\subsection{Concept of Vocabulary Mastery}

Teacher is as the mediator, facilitator and of course educator model to their students. What they do to the students is transfer knowledge moreover the students will be a good or bad one, it also based on the teacher itself. In teaching vocabulary in the classroom, it is just not only read and memorize the new word come from the textbook or other media, but also in outside the classroom they will exactly learn the new word from the media like TV, Article in the internet, magazine or even the pact of their snacks. Learning vocabulary is about understanding and memorizing the word that every single word has a lot of meanings and we have to put it in the suitable context.

Teaching vocabulary in the early English learning is very important. Students will find difficulties in learning English if they lack vocabulary. The vocabulary much more than grammar is the key to understand what students hears and reads in school, and to communicate successfully with other people. For this reason it is very important for students to build up a large store of words Shoebottom (2011). Vocabulary is the most important component language because it affects the four language skills. Related to the importance of vocabulary in language learning, Decarrico in Celce and Murcia (2001) states that vocabulary learning is central to language acquisition, whether the language first, second, or foreign. Because, we can know and see that the more the people master vocabulary the more they can understand language well. Vocabulary is essence of language. Without a sufficient vocabulary, the students cannot communicate effectively or express their idea in 
both oral and written form Fauziati (2005). Furthermore, she states that having limited vocabulary is also barrier to master a foreign language. Moreover Nation (2001) states that vocabulary in the classroom need repetition. Repetition is essential for vocabulary learning because there is so much to know about each word that one meeting with it is not sufficient to gain this information, so that they can be fluently accessed. Repetition adds to the quality and quantity of this knowledge. Scrivener (1994) also states that the roles of vocabulary in the classroom have five initial conclusions, they are;

a) Vocabulary is very important and needs to be dealt with systematically $n$ its own right; it is not simply and adds on grammar or skills lesson.

b) Our job does not finish as soon as a learner has first met some new vocabulary, we need to help them practice, learn, store, recall and use the items.

c) Training in the use of English, English dictionaries provides learners with a vital tool for self-study

d) We need to distinguish between the vocabulary for productive use and receptive recognition and adapt our classroom work appropriately.

e) We need to deal not only with single word lexical items, but also with longer, multi word items.

\section{METHOD AND DISCUSSION}

3.1 Using Games in Teaching

Games are fun activity for language learning. It allow for creativity, and higher order thinking. Wright (2006) Games are used as methods or techniques to involve students in learning. the benefits of games range from cognitive aspect of language learning to more cooperative group dynamics and as a result games are highly motivating since they are amusing and at the same time challenging. Games also help the teacher to create contexts in which the language is useful and meaningful.

According to Gerlach (1971) the advantages of using games in the classroom are as follows:

a) The student seeks to solve problems in which he/she is intimately involved.

b) The student is satisfied when he/she senses a new insight as new ideas and concepts are formulated.

c) The student is placed in a more realistic environment than in any other form of learning (except when the actual experience occurs).

d) A full range of audiovisual media can be used to create realistic simulated environments. Audiotapes, films, slides, television and other media offer opportunities to capture and distribute useful stimuli.

e) A high degree of interest is generated through realistic participation.

3.2 Charades game and its characteristics

Charade is a word guessing game. It is pantomime that involves body movement and facial expression are fun and encourage creativity and spontaneity. Glouberman (2003) says that charades game is a game using the face and the body to communicate. He furthermore notes some points that should be examined in the game:

a. Keeping from talking

b. Using physical communication skills (body, face, gestures, etc.)

c. Shared and non-shared cultural references

d. Learning to see things from the other person's perspective

e. Emotion in communicative: what to do when your partner frustrates you 
f. Development of specific vocabulary

g. Effects of competition on effectiveness and enjoyment.

Charades game is acting out words, actions or feeling in a text. This game makes the students guess every word by using their gestures, and can help them to remember the meaning of the word. It is an alternative way to teach the vocabularies. Charades game is a fun and entertaining game for all ages. By using this game, the students have good participants because they have high degree of interest and satisfied to learn something. Himmele (2011) states that take them to activities of higher level thinking. It is also a lot of fun when students are asked to do this is in a group. By this game, the students encourage thinking that done in groups, it makes them more comfortable in conducting activities in the classroom and outside, and using this game will facilitate them to learn vocabulary. Charades game not only helps the students in understanding the material but also makes them enjoyable during the learning and gives positive feedback for the teachers in teaching-learning process.

\subsection{The Procedures of Charades Game}

Here are some the steps or procedures in applying charades game in the classroom;

a. Firstly, before starting the game, it is better for the teacher to give warming up activity. For example; the teacher give a topic about animal, then she/he ask the students to mention kind of animal to make sure that the students have many vocabulary of it and ask to what the characteristics of those animal too to them. Then, divide the class into two teams since the game is a competition. Let the students know that they are going to have a Charade game and let them know that they will compete in team. The teacher then explains how to play the game and the rules of the games.

b. Secondly, the teacher or the team should list every word that will be given. Index cards might be useful as a tool. Then, the team write list of words in the index cards and put in a basket or box.

c. Thirdly, during the Charade game, the teacher has to make sure that all students involve and participate in the game. The teacher also takes a note for every mistake students made in guessing the words. Later, the teacher may discuss about the mistakes with the students. The point in Charade game sometimes is not in guessing the right words but much of the lesson is in the wrong guesses students make.

d. The last, after the Charade game is finished, the teacher can lead the class to post game discussion for reviewing the game and looking the students opinion about what had happened during the game. This is the perfect time for the teacher to lead the discussion to the topic that the teacher refers to.

\section{CONCLUSION}

Because to master the vocabulary in language learning is to be badly needed to the students and can give significant effect for them in acquiring four skills in English. In supporting the students to expand and enrich the vocabulary, the teacher has to use various learning strategies and aids in the classroom. Through the Charade game, the students may explore their vocabulary, and also the game is able to attract the learners' interest since there is a competition in that game furthermore the students can enjoy the vocabulary class without any doubtful or anxiety at all. 


\section{REFERENCES}

Andrew Wright, David Bettridge, Michael Buckby. (2006). Games for Language Learning. New York: Cambridge University Press.

Cameron, Lynne. (2001). Teaching Languages to Young Learners. Cambridge: Cambridge University Press.

Fauziati, Endang. (2005). Teaching of English as a Foreign Language (TEFL). Surakarta. Muhammadiyah University Press.

Glouberman, Misha. (2003). How to Get Very Good At Playing Charades. $\begin{array}{lllll}\text { Retrieved on } & \text { April } & 8^{\text {th }} & 2017 & \text { from }\end{array}$ http://www.room101games.com/charades/

Himmele, Persida \& William Himmele. (2011). Total Participation Techniques. Alexandria: Library of Congres Cataloging-in- Pablication Data.

Murcia, Marianne C.(2001). Teaching English as a Second or Foreign Language. USA: Heinle \& Heinle.

Nation, I.S.P. (2008). Teaching Vocabulary: Strategies and Technique. America: Heinle Cengange Learning.

Nunan, David. (2000). Language Teaching Methodology: A Textbook For Teachers. London: Pearson Education

Richard, Jack and Renandya. (2002). Methodolgy in Langauge Teaching: An Anthology of Current Practice. New York: Cambridge University Press.

Scrivener. Jim. (1994). Learning Teaching. Heinemann.

Shoebottom. (2011). The Importance of Vocabulary. Frankfurt International School, Available at http://esl.fis.edu/parents/advice/vocab.htm, retrieved on April 22 $2^{\text {nd }}, 2017$.

Vernon S Gerlach, (1971).Teaching and Media. New York: Prentice-Hall.

Virginia,French Allen. (1983). Tehniques in Teaching Vocabulary. New York: Oxford University Press.

Wanzek, Jeanne. (2003). Vocabulary instruction. Retrieved on June 13th 2017, from

http://www.texasreading.org/3tier/components/vocabulary_activies.asp 